\title{
Identification of Active Compounds of Kepok Banana Peel and the Effect on Testosterone Concentration in Male Rats with High-Fat Diet
}

\author{
Baidillah Zulkifli ${ }^{1}$, Muslim Akmal2 $^{*}$, Sri Wahyuni ${ }^{3}$, Tongku N. Siregar ${ }^{4}$, and Gholib Gholib ${ }^{5}$ \\ ${ }^{1}$ Master of Veterinary Public Health Study Program, Faculty of Veterinary Medicine, Syiah Kuala University, Banda Aceh, Aceh, \\ Indonesia \\ ${ }^{2}$ Laboratory of Histology, Faculty of Veterinary Medicine, Syiah Kuala University, Banda Aceh, Aceh, Indonesia; \\ ${ }^{3}$ Laboratory of Anatomy, Faculty of Veterinary Medicine, Syiah Kuala University, Banda Aceh, Aceh, Indonesia; \\ ${ }^{4}$ Laboratory of Reproduction, Faculty of Veterinary Medicine, Syiah Kuala University, Banda Aceh, Aceh, Indonesia; \\ ${ }^{5}$ Laboratory of Physiology, Faculty of Veterinary Medicine, Syiah Kuala University, Banda Aceh, Indonesia
}

\begin{abstract}
Our body needs an adequate supply of antioxidants to maintain physiological functions. Antioxidant compounds are found in natural plants, including inside of kepok bananas peel. This research was conducted to determine the potential of kepok banana peels to maintain testosterone concentration in male rats (Rattus norvegicus) with a high-fat diet. This study used 20 male rats 2.5-3 months old, which grouped into 5 groups: normal group given standard feed (K1), negative control group given high-fat diet (K2), positive control group given high-fat diet and simvastatin (K3), high-fat diet group and banana peel extract administered at $100 \mathrm{mg} / \mathrm{kg} \mathrm{BW}$ (K4), and high-fat diet group and banana peel extract administered at $200 \mathrm{mg} / \mathrm{kg} \mathrm{BW}$ (K5). The blood serum was collected after 60 days of the treatment. The blood serum testosterone levels were measured by enzyme-linked immunosorbent assay (ELISA) method at a wavelength of $450 \mathrm{~nm}$. The major findings of this study were that there is a significant difference between testosterone concentrations by the $\mathrm{K} 4$ group compared to $\mathrm{K} 2$ and $\mathrm{K} 5$ groups $(\mathrm{P}<0,05)$. The result suggests that the dose $100 \mathrm{mg} / \mathrm{kg} \mathrm{BW}$ of banana peel extract has the potential to maintain the testosterone concentration in male rats with a high-fat diet.
\end{abstract}

Keywords: kepok banana peel, active components, high-fat diet, testosterone.

\section{Introduction}

The development of derived herbal medicines as alternative medicines has been intensively studied in recent years. Herbal medicines contain antioxidants such as vitamin $\mathrm{E}$, vitamin $\mathrm{C}$, phenol and flavonoids [1]. These bioactive compounds can be found in plants one of which is in the banana peel. Someya et al. [2] reported that banana peels have higher antioxidant activity than the banana flesh. The antioxidants in banana peel compounds are pectin, tannins, saponins, and flavonoids [3]. The results of Edenta et al. [4] research proved that the effect of banana peel extract in decreasing low-density lipoproteins (LDL) and triglycerides concentration was comparable to Atorvastatin which commonly used for cholesterol-lowering drug and hyperlipidemia. This proves the banana peels are the potential to inhibit the LDL increase that can reduce the possibility of hyperlipidemia caused by a high-fat diet.

Excessive high-fat diets can interfere with cholesterol homeostasis and then disrupts the normal functioning of the reproductive organs (Pushpendra and Jain, 2015). The interfere should occur for active cholesterol transport system disorders that cause lipid peroxidation in the Leydig cell membrane [5]. According to Rachmadi [6] and Al-Damegh [7], Leydig cells play an important role in producing the testosterone hormone which provides sexual stimulation (libido) in male animals. In addition, testosterone also plays an important role in spermatogenesis, especially in the spermiation stage [8-10]. Disruption of the spermatogenesis process might cause infertility in male animals [11].

In recent years, Many alternative medicines have been developed from herbal plants that can inhibit the negative effects of a high-fat diet. However, the effectiveness of the active compounds of kepok banana peel extract on testosterone concentration in male rats with a high-fat diet is still absent.

\section{Materials and Methods}

This study used $7 \mathrm{~kg}$ kepok banana peel and 20 adult male rats (Rattus norvegicus) aged 2.5-3 months and body weight ranged from 120-160 grams. The samples used in this study were blood plasma. Permit for use of experimental animals has been approved by the

* Corresponding author: akmal_kh@unsyiah.ac.id 
Veterinary Ethics Committee, Faculty of Veterinary Medicine, Syiah Kuala University.

\subsection{Animal Treatments}

This research used experimental designed with a completely randomized design consists of five groups. Each of the groups consisted of four replications, coded $\mathrm{K} 1, \mathrm{~K} 2, \mathrm{~K} 3, \mathrm{~K} 4$, and $\mathrm{K} 5$. Before treatment, all groups were adapted for two weeks. After the adaptation phase, $\mathrm{K} 1$ (normal control) is given standard feed, K2 (negative control) is given high-fat feed, K3 (positive control) is given high-fat feed and simvastatin, $\mathrm{K} 4$ is given high-fat feed and banana peel extract is $100 \mathrm{mg} / \mathrm{kg} \mathrm{BW}$, and K5 were given high-fat feed and banana peel extract as much as $200 \mathrm{mg} / \mathrm{kg} \mathrm{BW}$. The high-fat feed is modified from Heriansyah [12], it was 5\% wheat flour, $2 \%$ waste cooking oil, 1,5\% yolk and 5\% beef fat. High-fat feeds are given ad-libitum, while carboxyl methylcellulose (CMC), simvastatin and kepok banana peel extract are given by oesophageal tube feeding method. Standard fed was given as much as $7 \mathrm{gr} / \mathrm{day}$.

\subsection{Preparation of Kepok Banana Peel Extract}

The kepok Banana sent to the Botanical Laboratory of Biology-LIPI Research Center for identification and determination. The procedure of kepok banana peel extraction based on the modification research by Pratama et al. [13]. The kepok banana peel which used in this study was the raw green. $7 \mathrm{~kg}$ of kepok banana peel were cleaned and cut into small pieces $( \pm 0.5 \mathrm{~cm})$ and then dried on a tray by aerated in the room for 2 weeks. Dry banana peels were mashed by blender to form a powder. Banana peels powder weighed $100 \mathrm{~g}$ and macerated using $70 \%$ ethanol for 72 hours and then filtered. This maceration process is repeated until maserat produced. The obtained extract ware concentrated with a vacuum rotary evaporator at $60^{\circ} \mathrm{C}$ until obtained a thick extract. The effective dose of kepok banana peel extract in mice refers to Onansanwo's research [14], which were $100 \mathrm{mg} / \mathrm{kg}$ body weight and $200 \mathrm{mg} / \mathrm{kg}$ body weight given orally with a volume of $1 \mathrm{ml}$.

\subsection{Testosterone Measurement}

Measurement of testosterone concentrations was conducted using a commercial testosterone enzymelinked immunsorbent oassay (ELISA) kit (Cat. No. EIA1559, DRG, Instrument Diagnostic GmbH, Germany) as described by Gholib et al. [27]. This assay has been used and validated for other animals [27,40,41]. Plasm samples were diluted using aquabidestilates in a ratio of 1: 4 . Before the analysis is carried out, standard solutions prepared in concentrations of $0.2 \mathrm{ng} / \mathrm{ml}$ to $16 \mathrm{ng} / \mathrm{ml}$ and controls (QCs). Samples, standard solutions, and QCs were filled into ELISA microplate wells as much as 25 $\mu \mathrm{L}$, then added $200 \mu \mathrm{L}$ of conjugate enzymes to each well except blank wells, then covered with cling film and homogenized by slowly shaking for 10 seconds. After that, microplate incubated for 60 minutes at room temperature. After incubating, microplate was washed with $300 \mu \mathrm{L}$ washing solution each wells 4 times. After that, $200 \mu \mathrm{L}$ substrate solution filled into each well and then covered with cling film and incubated for 15 minutes at room temperature. The enzymatic reaction was stopped by adding $100 \mu \mathrm{L}$ stop solution ( $5 \mathrm{M} \mathrm{H}_{2} \mathrm{SO}_{4}$ ) into each well and absorbance was read using an ELISA reader at $450 \mathrm{~nm}$ of wavelength. Concentration of testosterone was calculated using the MPM6 program.

\subsection{Data analysis}

The testosterone concentration data from each treatment group were analyzed using analysis of variance (ANOVA) and Post hoc test using a Duncan's test.

\section{Results and Discussion}

\subsection{Results of Kepok Banana Peel Extract Compounds}

Based on the results of the identification and determination of banana peel samples at the Botanical Laboratory of Biology-LIPI Research Center, it was found that the type of banana peel is Musa acuminate $x$ Musa balbasiana (ABB).

Based on phytochemical tested of the presence of the active compounds in kepok banana peel extract as much as 25,82 gr obtained results in Table 1 .

Table 1. Active compounds of banana peel.

\begin{tabular}{ll}
\hline Type of compounds & Results \\
\hline Alkaloid & + \\
Flavonoid & + \\
Tannin & + \\
Saponin & + \\
Steroid/Triterpenoid & + \\
\hline Note: $(+)=$ positive representation of compounds.
\end{tabular}

Conducted phytochemical examination aimed to detect the presence of active compounds in natural materials. Saponin test on banana peel extract was positive if foam formed with a lot of intensity for 10 minutes after the solution stirred and allowed to stand for 10 minutes. Saponin is a bioactive compound that can inhibit exogenous cholesterol biosynthesis [15]. Saponin compounds work by binding cholesterol with bile acids so that they can reduce levels of low-density lipoprotein (LDL) fat in the blood [16].

The samples of banana peel extract showed positive for alkaloids. Alkaloid testing is positive if the Mayer test formed white or yellow deposits, Bouchardat test formed brown deposits, and Dragendorf test formed orangeyellow deposits. Samples tested positive for tannins when blue or green are formed in the reagent solution. While samples that contain positive flavonoids characterized by a yellow, red or brown color change that is very striking when tested using $\mathrm{H}_{2} \mathrm{SO}_{4}$ reagents. Flavonoids contained in kepok banana peels belong to the largest group of phenol compounds consisting of fifteen carbon atoms with two benzene rings [17]. According to Bigoniya and 
Singh [18], the mechanism of flavonoids to protect our body from free radicals is by preventing lipid peroxidation. As an antioxidant, flavonoids act by reducing LDL in the body [19].

Banana peel extract also contains active compounds of steroids which evidenced by changes in blue, purple or green in reagents and contain triterpenoids due to red or brown discoloration. Steroids are a group of antioxidant that has antifungal effects and commonly used as raw materials for the biosynthesis of corticosteroid drugs. While triterpenoids are derivatives of $11 \beta$-amyirine which easily crystallized through acetylation and can be used to reduce levels of LDL [20, 21].

Based on the results of phytochemical tests (Table 1), kapok banana peel extract contains five types of active compounds. This proves that banana peel extract is a potential candidate for antioxidants and natural herbal medicines. Several studies have shown that from all parts of the banana plant, banana peels have the highest antioxidant activity. The antioxidant activity on banana peels reaches $94.25 \%$ at a concentration of $125 \mu \mathrm{g} / \mathrm{ml}$ compared to the portion of bananas flesh which only $70 \%$ at a concentration of $50 \mathrm{mg} / \mathrm{ml}$ [22-24]. This antioxidant activity that causes banana peels can reduce LDL $[25,26]$.

\subsection{Testosterone concentrations}

The results of the serum testosterone concentrations in male rats in each treatment group for 60 days were presented in Table 2.

Table 2. The statistical analysis results of testosterone concentration in $\mathrm{ng} / \mathrm{mL}$ by the Duncan test.

\begin{tabular}{ll}
\hline Treatment group & $\begin{array}{l}\text { testosterone } \\
\text { concentration } \\
\text { (Mean } \pm \text { SE) }\end{array}$ \\
\hline $\mathrm{K} 1$ & $3,8443 \pm 2,84^{\mathrm{ab}}$ \\
$\mathrm{K} 2$ & $1,2783 \pm 0,67^{\mathrm{bc}}$ \\
$\mathrm{K} 3$ & $1,8780 \pm 1,54^{\mathrm{abc}}$ \\
$\mathrm{K} 4$ & $4,3248 \pm 1,61^{\mathrm{a}}$ \\
$\mathrm{K} 5$ & $0,5045 \pm 0,14^{\mathrm{c}}$ \\
\hline
\end{tabular}

Note: Different superscript in each treatment group show a significant difference $(\mathrm{p}<0.05)$

Based on the results of the statistical analysis of the five male rat treatments showed a decrease in the concentration of testosterone hormone in the $\mathrm{K} 2$ treatment group compared with the K1 treatment group although this decrease did not show any significant difference $(\mathrm{P}>$ $0.05)$. Testosterone was seen to be slightly increased in the $\mathrm{K} 3$ treatment group compared to the $\mathrm{K} 1$ and $\mathrm{K} 2$ treatment groups.

Decrease of the testosterone hormone concentration in the $\mathrm{K} 2$ treatment group (high-fat feeding) was thought to be due to the body's inability to reduce the negative effects of high-fat feeding. According to Bashandi [28], longterm a high-fat diet can cause hyperlipidemia followed by increasing production of reactive oxygen species (ROS) and lipid peroxidation. The high-fat concentration in bloodstream positively correlated with the onset of various disorders of reproductive function such as inhibition of testosterone and luteinizing hormone (LH) secretion, degeneration of Leydig cell, and spermatogenesis disorders. According to Khatimah [29], the inhibition of gonadotropin-releasing hormone $(\mathrm{GnRH})$ inducing Leydig cells in rat closely related with modification in three pathways, (1) loss of hormone receptors (downregulation hormone), (2) decreased cyclic adenosine monophosphate (cAMP) response and (3) decrease in androgen production capacity.

According to Darbandi et al. [30], many factors can influence the increase in ROS in the reproductive system. If the ROS increases continuously, it will cause activation of the hypothalamic-pituitary-adrenal axis (HPA) to release corticosterone (in animals) or cortisol (in humans) to respond to the oxidative stress. This stress hormone stimulates the hypothalamic-pituitary-gonadal axis (HPG) to reduce LH secretion in the pituitary gland. The low concentration of LH causes a decrease in the stimulation of Leydig cells to produce enough testosterone.

Leydig cells play an important role in testosterone hormone regulation. According to Widhiantara et al. [31], Rats fed with high-fat feed in the long period will experience a decrease in the number of Leydig cells caused by hyperlipidemia. Hyperlipidemia can trigger to increase ROS compounds, disruption of the hypothalamus-pituitary axis, thereby decreasing LH secretion and disrupting the stimulation of Leydig cells to produce testosterone [28, 32].

The K4 treatment group showed the highest testosterone increase compared to the K1 and K3 treatment groups but did not show any significant difference $(\mathrm{P}>0.05)$. The $\mathrm{K} 4$ treatment showed a marked difference in the concentration of testosterone hormone increase compared to the $\mathrm{K} 2$ treatment $(\mathrm{P}<0.05)$. This increase caused by the inhibiting negative process of highfat feed by banana peel extract. The high-fat feed can induce oxidative stress, disrupt in membranes permeability, impaired function of sodium pumps in cell membranes and followed by the formation of ROS. According to Werdhasari [33], antioxidants needed by the body to neutralize the effects of ROS and prevent damage caused by it. Antioxidant compounds contained in banana peels are reported to have biological and pharmacological effects which can reduce the negative effects of free radicals [34, 35].

A decrease in testosterone concentration was shown in the $\mathrm{K} 5$ treatment group $(\mathrm{P}<0.05)$. This is probably due to the excessive breaking of the saturated fat chain that disrupts the function of the LH formation thereby reducing the formation process of the testosterone hormone. According to Brinkmann [36], LH increases the activity of enzymes that will convert cholesterol into the testosterone hormone. Decrease of LH secretion from the anterior pituitary causes degeneration of Leydig cells which results in low production of the testosterone hormone. The results of this study are in line with the statement of Bast and Haenen [37], that antioxidants derived from natural contents also have a limit does consumption.

The previous study has proven that the decrease in testosterone affects libido decreasing, disruption of 
spermatogenesis and seminiferous tubule diameter. If the concentration of the testosterone hormone is too high or too low (below the normal threshold) will result in negative feedback to the hypothalamus which further interferes with spermatogenesis. Conversely, if the testosterone hormone concentration is normal, it will stimulate the testes to process the spermatogenesis [38, 39].

\section{Conclusion}

Kepok banana peel extract with a dose of $100 \mathrm{mg} / \mathrm{kg}$ body weight given for 60 days has the potential to increase the concentration of white rat testosterone. While means giving kepok banana peel extract with a dose of 200 $\mathrm{mg} / \mathrm{kg}$ bodyweight for 60 days can interfere with the formation of testosterone in white rats.

\section{Acknowledgment}

The researcher would like to thanks to Nora Usrina and Siti Prawitasari Hasibuan for their help during this research.

\section{References}

1. Speisky H, Pena A, Gomez M, et al: Antioxidants in chilean berries. Acta Hortic. 2008; 777: 485-492.

2. Someya S, Yoshiki Y, Okubo K: Antioxidant compounds from bananas (Musa cavendish). Food Chemistry. 2002; 79(3): 351-354.

3. Andini NAM: Pengaruh pemberian ekstrak etanol kulit pisang ambon dan kulit pisang kepok terhadap kadar kolesterol total tikus putih jantan galur sprague dawley. Skripsi. Universitas Lampung. 2014.

4. Edenta C, James DB, Owolabi OA, et al: Hypolipidemic effects of aqueous extract of three cultivars of Musa sapientum fruit peel on poloxamer-407 induced hyperlipidemic Wistar rats. I.J.P.S.R. 2014; 5(12): 10491054.

5. Husain K, Somani SM: Interaction of exercise training and chronic ethanol ingestion on testicular antioxidant system in rat. J. Appl. Toxicol. 1998; 18: 421-429.

6. Rachmadi A: Kadar gula darah dan kadar hormon testosteron pada pria penderita diabetes melitus. Tesis. Fakultas Kedokteran, Universitas Diponegoro. 2008.

7. Al-Damegh MA: Stress-induced changes in testosterone secretion in male rats: role of oxidative stress and modulation by antioxidants. J. Animal Sci. 2014; 4: 7078.

8. Rachmawati L, Ismaya, Astusi P: Korelasi antara hormon testosteron, libido, dan kualitas sperma pada kambing bligon, kejobong, dan peranakan etawah. Buletin Peternakan. 2014; 38(1): 8-15.

9. Akmal M, Aulanni'am, Widodo MA et al: The important role of protamine in spermatogenesis and quality of sperm: A mini review. Asian Pac. J. Reprod. 2016; 5(5): 357-360.
10. Akmal M, Gholib G, Rinidar R et al: The concentration of testosterone, pituitary adenylate cyclase-activating polypeptide, and protamine 1 in the serum of male chicken following administration of epididymis and testicular extracts and their combination. Vet. World. 2019; 12(7): 1101-1107.

11. Akmal M, Siregar TN, Wahyuni S et al: The expression of cyclic adenosine monophosphate responsive element modulator in rat Sertoli cells following seminal extract administration. Vet. World. 2016; 9: 1001-1005.

12. Heriansyah T: Pengaruh berbagai durasi pemberian diet tinggi lemak terhadap profil lipid tikus putih (Rattus novergicus strain wistar) jantan. JKS. 2013; 13 (3): 144150.

13. Pratama HY, Ernawati, Mahmud NRA: Uji antibakteri kulit pisang kepok (Musa paradisiaca $x$ balbisiana) mentah terhadap pertumbuhan bakteri pertumbuhan bakteri Staphylococcus aureus. J. Sainsmat. 2018; 7(2): 147-152.

14. Onansanwo S: Anti ulcer and ulcer healing potentials of methanol extract of Musa Sapientum peel in laboratory rats. Pharmacognosy Res. 2013; 5(3): 173-178.

15. Kusuma IW, Kuspradini H, Arung ET et al: Biological activity and phytochemical analysis of three Indonesian medicinal plants, Murraya koenigii, Syzygium polyanthum, and Zingiber purpurea. J. Acupunct. Meridian Stud. 2011; 4: 75-79.

16. Afrose $\mathrm{S}$, Hossain MS, Maki $\mathrm{T}$ et al: Karaya root saponin exerts a hypocholesterolemic response in rats fed a high-cholesterol diet. Nutr. Res. 2009; 29: 350-354.

17. Lenny S: Senyawa Flavonoida, Fenil Propanoida dan Alkaloida. Karya Ilmiah. Universitas Sumatera Utara, Medan. 2006

18. Bigoniya $\mathrm{P}$, Singh K: Original article ulcer protective potential of standardized hesperidin, a citrus flavonoid isolated from Citrus sinensis Papiya Bigoniya. Rev. Bras. Farmacogn. 2014; 24(3): 330-400.

19. Radhika S, Smila KH, Muthezhilan R: Antidiabetic and hypolipidemic activity of Punicagranatum linn on alloxan induced rats. Int. J. Med. Sci. 2011; 6(4): 178-182.

20. Prihatman K: Saponin untuk Pembasmi Hama Udang. Bandung: Penelitian Perkebunan Gambung. 2001.

21. Andini NAM: Pengaruh pemberian ekstrak etanol kulit pisang ambon dan kulit pisang kepok terhadap kadar kolesterol total tikus putih jantan galur sprague dawley. Skripsi. Universitas Lampung. 2014.

22. Fatemeh SR, Saifullah R, Abbas FMA et al: Total phenolics, flavonoids, and antioxidant activity of banana pulp and peel flours: Influence of variety and stage of ripenes. Int. Food Res. J. 2012; 19(3): 1041-1046.

23. Shodehinde SA, Oboh G: Antioxidant properties of aqueous extractsof unripe Musa paradisiaca on sodium nitroprusside induced lipid peroxidation in rat pancreas in vitro. Asian Pac. J. Trop. Biomed. 2013; 3(6): 449-457.

24. Padilla-Camberos E, Flores-Fernández JM, CanalesAguirre AA et al: Wound healing and antioxidant capacity of Musa paradisiaca Linn. peel extracts. J.P.P.Res. 2016; 4(5): 165-173. 
25. Atun S, Arianingrum R, Handayani $\mathrm{S}$ et al: Identifikasi dan uji aktivitas antioksidan senyawa kimia dari ekstrak metanol kulit buah pisang (Musa paradisiaca Linn.). Indo. J. Chem. 2007; 7(1): 83-87.

26. Ratnawati $\mathrm{H}$, Widowati $\mathrm{H}$ : Anticholesterol activity of velvet bean (Mucuna pruriens L.) towards hypercholesterolemic rats. Sains Malay. 2011; 40(4): 317-321.

27. Gholib G, Wahyuni S, Akmal M, et al. : The validation of a commercial enzyme-linked immunosorbent assay and the effect of freeze-thaw cycles of serum on the stability of cortisol and testosterone concentrations in Aceh cattle [version 1; peer review: 1 approved, 1 approved with reservations]. F1000Research 2019, 8:1220.

28. Bashandy AES: Effect of fixed oil Nigella sativa on male fertility in normal and hyperlipidemic rats. Int. J. Pharmacol. 2007; 2(1): 104-109.

29. Khatimah $\mathrm{H}$ : Kadar testosteron intratestikular tikus Rattus novergicus strain Sprague dawley akibat pemberian kurkumin setelah stimulasi hCG. Berkala Kedokteran. 2015; 11(2): 189-197.

30. Darbandi M, Darbandi S, Agarwal A et al: Reactive oxygen species and male reproductive hormones. Reprod. Biol. Endocrinol. 2018; 16(87): 1-14.

31. Widhiantara IG, Permatasari AAAP, Siswanto FM et al: Ekstrak daun sembung (Blumea balsamifera) memperbaiki histologi testis tikus wistar yang diinduksi pakan tinggi lemak. J.B.B.I. 2018; 5(2): 111-118.

32. Kartiko BH, Siswanto FM: Overtraining elevates serum protease level, increases renal p16INK4a gene expression and induces apoptosis in rat kidney. Sport Sci. Health. 2018 14: 331-337.
33. Werdhasari A: Peran antioksidan bagi kesehatan J.B.M.I. 2014; 3(2): 59-68.

34. Rebello LPG, Ramos AM, Pertuzatti PB et al: Flour of banana (Musa AAA) peel as a source of antioxidant phenolic compounds. Int. Food Res. J. 2014; 55: 397-403.

35. Pereira A, Maraschin M: Banana (Musa spp) from peel to pulp: ethnopharmacology, source of bioactive compounds and its relevance for human health. $J$. Ethnopharmacol. 2015; 160: 149-163.

36. Brinkmann AO: Androgen physiology: Receptor and metabolic disorders. Rotterdam, Netherlands. 2009.

37. Bast A, Haenen GRMM: The toxicity of the antioxidants and their metabolites. Environ. Toxicol. Pharmacol. 2002; 11: 251-258.

38. Nurliani A, Rusmiati, Santoso HB: Perkembangan sel spermatogenik mencit (Mus musculus L.) setelah pemberian ekstrak kulit kayu durian (Durio zibethinus Murr.). Berk. Penel. Hayati. 2005; 11: 77-79.

39. Walker WH, Cheng J: FSH and testosterone signaling in Sertoli cells. Reproduction. 2005; 130(1): 15-28.

40. Gholib G, Wahyuni S, Kadar OK et al. : Measurement of serum testosterone in kacang goat by using enzymelinked immunosorbent assay (ELISA) technique: the importance of kit validation. Jurnal Kedokteran Hewan, 2016, 10(1):32-36

41. Akmal M, Gholib G, Rinidar at al. : The concentration of testosterone, pituitary adenylate cyclase-activating polypeptide, and protamine 1 in the serum of male chicken following administration of epididymis and testicular extracts and their combination. Veterinary World. 2019, 12(7): 1101-1107. 